\title{
East Germany's Red Woodstock: The 1973 Festival between the "Carnivalesque" and the Everyday
}

\author{
Katharine White
}

\begin{abstract}
Scholars often depict the 1973 World Festival of Youth and Students—or, more colloquially, the Red Woodstock-as a momentary "departure" or "break" from everyday life, when the German Democratic Republic (GDR) briefly opened its borders to the youth of the world. Similarly, they suggest that, when the festival's nine days of festivities came to an end, the "pathos of revolution" disappeared just as quickly as it had come about, resulting in a return to the restraints of everyday life behind the "Iron Curtain." By contrast, this article reconsiders the festival's significance by adopting an analytical framework from postsocialist theorists. In doing so, it reconceptualizes the Red Woodstock as a moment of globalized influences and youth engagement that not only reflected shifting societal norms, but also the East German state's commitment to international socialist solidarity. Soviet theorist Mikhail Bakhtin's work on the "upside-down" nature of the carnival, as well as on society's "grotesque body," is useful in this regard, as it sets in sharp relief the extent to which one of the East German state's greatest challenges resulted from its own embrace of international socialism. This was the case as young people from the GDR and beyond transformed the East German capital through a subtle appropriation, transformation, and even subversion of the state-generated discourse on international solidarity, in ways that had a lasting effect during the late socialist period.
\end{abstract}

Die Weltfestspiele der Jugend und Studenten des Jahres 1973 - auch das rote Woodstock genannt -, anlässlich derer die DDR kurzzeitig ihre Grenzen für Jugendliche aus aller Welt öffnete, wurden von Forschern oft als vorübergehende „Abweichung“ oder kurzer „Bruch“ mit dem alltäglichen Leben in der DDR dargestellt. In diesem Sinne unterstellen besagte Forscher, dass das „Pathos von Revolution“ nach den neun Tagen andauernden Festivitäten genauso schnell verschwand, wie es gekommen war, und in eine Rückkehr der alltäglichen Zwänge jenseits des „Eisernen Vorhangs“ mündete. Im Gegensatz dazu überdenkt dieser Aufsatz die Bedeutung des Festivals mit Hilfe eines postsozialistischen Interpretationsrahmen. Dabei wird das rote Woodstock als Moment globalisierter Einflüsse und jugendlichen Engagements umgedacht, der nicht nur im Wechsel begriffene gesellschaftliche Normen, sondern auch den Einsatz des ostdeutschen Staates für internationale sozialistische Solidarität reflektierte. Besonders nützlich sind hierbei die Arbeiten des sowjetischen Theoretikers

I would like to thank my $\mathrm{PhD}$ adviser, Andrew Zimmerman, as well as Jonathan Zatlin, Timothy Brown, Katrin Schultheiss, and Hugh Agnew, who have commented on various iterations of the dissertation chapter upon which this article builds. I am indebted to Geoff Eley for suggesting that I research the Red Woodstock festival for my dissertation. I also appreciate the comments provided by Dina Khoury, Scott Harrison, and Robert Isaacson during different phases of the article. The research for the article was completed with generous support from the German Historical Institute in Washington, D.C., the German Academic Exchange Service, a Bernadotte E. Schmitt Grant from the American Historical Association, as well as fellowships from the Institute for European, Russian, and Eurasian Studies and the History Department at George Washington University. I also want to thank the anonymous reviewers and the journal editor, Andrew I. Port, for their insightful comments. 
Mikhail Bakhtin über die „,verkehrte“ Natur der Karnevalszeit und den ,grotesken Körper“ der Gesellschaft, da sie das Ausmaß, zu dem die größten Herausforderungen des ostdeutschen Regimes während des späten Sozialismus von dessen eigener Annahme internationaler Solidarität via seiner Solidaritätsagenda resultierten, deutlich hervorhebt: Junge Leute aus und jenseits der DDR transformierten die ostdeutsche Hauptstadt durch subtile Appropriation, Transformation und sogar eindeutige Subversion des staatskontrollierten Diskurs über internationale Solidarität, und zwar auf eine Art und Weise, die während der spätsozialistischen Zeit einen bleibenden Effekt haben sollte.

$\mathrm{I}$ $\mathrm{N}$ the summer of 1973, East Germany hosted a much anticipated socialist youth festival, the tenth World Festival of Youth and Students, which many subsequently referred to more simply as the Red Woodstock. Under the banner of "anti-imperialist solidarity, peace, and friendship," the festival in East Berlin convened twenty-five thousand international participants, as well as hundreds of thousands of East German youths and guests, for nine days of music performances, art exhibitions, sports events, and political seminars-all in the name of international socialism. ${ }^{1}$ Yet, in looking back at the events, participants and scholars alike would cast the festival as a "break" or momentary rupture from the everyday realities of really existing socialism..$^{2}$ Ina Merkel, a young attendee who became a scholar of East German cultural studies, later reflected: "I think that afterwards everything was as before ... I believe that, for the young people who had taken part in it, it had been a very important experience in their lives. And, for them, a return to normality meant an awakening, also back to the restrictive situation. So they woke up again; they became depathologized again, i.e., the pathos of the revolution was gone." ${ }^{3}$ In recognizing the Red Woodstock as a singular moment embodying young people's international revolutionary zeal, Merkel points to its significance as an aberration rather than as a reflection of East German everyday life. Her comment reflects a common sentiment - namely, that the "revolutionary pathos" that the festival engendered might be understood as antithetical to the state socialist project.

Scholars often interpret festivals as aberrations or departures from the norm, as a time when society's creative potential is unleashed, before being once again stifled-or, in the East German case, redisbursed to the hidden niches of society. ${ }^{4}$ Such notions have their antecedents in studies of the European carnival of the Middle Ages and Renaissance period. In his

\footnotetext{
${ }^{1}$ This article draws extensively from the first chapter of my dissertation, “The 'Red Woodstock' Festival and the Making of an International Youth Culture in the East Berlin Cityscape during Late Socialism, 19701990s" (PhD diss., George Washington University, 2018). East Berlin was the heart of the 1973 festival, but youth activities occurred across the German Democratic Republic (GDR). The East German state organized countless meetings, predominantly for members of the official Free German Youth (FDJ) and international guests, many of which occurred behind closed doors.

${ }^{2}$ Phillip Dyck, a participant at the festival who later became a cultural minister of the FDJ, described the festival as an "Aufbruch" (departure, break, or new start). Phillip Dyck, in discussion with the author, Berlin, Nov. 2014. Other participants used similar terminology.

${ }^{3}$ Ina Merkel attended the festival at age fourteen, though not as an official participant. See her interview, "Hinterher war alles beim Alten," on the website of the Bundeszentrale für politische Bildung (http://www. bpb.de/geschichte/deutsche-geschichte/weltfestspiele-73/65303/hinterher-war-alles-beim-alten).

${ }^{4}$ There is a well-established body of scholarship on the "niche" as a metaphor for understanding how East Germans lived authentic private lives under the East German dictatorship. Much of this is based on Günter Gaus, Wo Deutschland liegt: Eine Ortsbestimmung (Hamburg: Hoffmann \& Campe, 1983). Scholars have increasingly abandoned the concept, adopting methods from Alltagsgeschichte (the history of everyday
} 
seminal account, Rabelais and His World, Soviet theorist Mikhail Bakhtin-whose work remains influential in postsocialist theory-highlights an image of the carnival in which the world was turned "upside down." He suggests that "the carnival celebrated temporary liberation from the prevailing truth and from the established order; it marked the suspension of all hierarchical rank, privileges, norms, and prohibitions." As Bakhtin further points out, "this temporary suspension, both ideal and real, of hierarchical rank created during carnival time a special type of communication impossible in everyday life." In essence, the carnival of the Middle Ages - like the festival of the modern era-was depicted as embodying a departure from everyday societal structures, representing a fleeting moment of authentic individual expression, genuine performances, and unhindered lived experience.

This article sets out to destabilize the idea that the 1973 festival exemplified a subversion of everyday life, by instead conceptualizing the Red Woodstock as a moment of globalized influences and youth engagement that reflected not only shifting societal norms, but also the East German state's commitment to international solidarity. ${ }^{6}$ On the one hand, this reassessment of the Red Woodstock enables us to move beyond flattened depictions of the festival as a false rendering of East German society. ${ }^{7}$ Stefan Wolle, for instance, argues that the festival served as little more than a "Potemkin Village," with the ever-present security apparatus of the police and Ministry for State Security (MfS, or Stasi) disciplining the festival participants from behind the scenes. ${ }^{8}$ On the other hand, this reinterpretation allows us to recognize the festival as more than a rare instance of authentic interactions between East Germans and the world at large, as Ina Merkel and Ina Rossow have depicted it (though Merkel recognizes the festival's significance in establishing an East German ritualized youth culture as well). ${ }^{9}$ The problem with such interpretations is that modern festivals are seldom short-lived moments of controlled chaos, but rather deeper reflections of state and societal rituals, youth trends and behavior, as well as the ever-shifting boundaries of

life). See, e.g., Mary Fulbrook, The People's State: East German Society from Hitler to Honecker (New Haven, CT: Yale University Press, 2005).

${ }^{5}$ Mikhail Bakhtin, Rabelais and His World, trans. Hélène Iswolsky (Bloomington: Indiana University Press, 1984), 10. Bakhtin's work has been utilized in recent postsocialist theoretical reinterpretations of state socialism, including in Alexei Yurchak, Everything Was Forever, Until It Was No More: The Last Soviet Generation (Princeton, NJ: Princeton University Press, 2005).

${ }^{6}$ This rereading of the festival builds on Peter Stallybrass and Allon White, The Politics and Poetics of Transgression (Ithaca, NY: Cornell University Press, 1986), 1-26.

${ }^{7}$ For a recognition of the festival as both a propaganda tool and a mechanism to generate youth interest, see Marc-Dietrich Ohse, Jugend nach dem Mauerbau. Anpassung, Protest und Eigensinn (DDR 1961-1974) (Berlin: Ch. Links Verlag, 2003), 340, 351-54.

${ }^{8}$ Stefan Wolle, Die heile Welt der Diktatur. Alltag und Herrschaft in der DDR 1971-1989 (Berlin: Ch. Links Verlag, 1998), 164. On the mobilization of youth and on the various facets of the festival, see Denise Wesenberg, Unter "operativer Kontrolle”: Die X Weltfestspiele der Jugend und Studenten 1973 in Ost-Berlin (Erfurt: Landeszentrale für politische Bildung, 2007); on the discrepancies between ideology and reality, see Andreas Ruhl, Stalin-Kult und Rotes Woodstock: Die Weltjugendfestspiele 1951 und 1973 in Ostberlin (Marburg: Tectum Press, 2009).

${ }^{9}$ Ina Merkel, "Im Spiegel des Fremden: Die Weltfestspiele von 1973," Kulturation: Online Journal für Kultur, Wissenschaft und Politik 2 (2003) (http://www.kulturation.de/ki_1_thema.php?id=30); Ina Rossow, “'Rote Ohren, roter Mohn, sommerheiße Diskussion'. Die X Weltfestspiele der Jugend und Studenten 1973 als Möglichkeit für vielfältige Begegnungen," in Fortschritt, Norm und Eigensinn. Erkundungen im Alltag der DDR, ed. Dokumentationszentrum Alltagskultur der DDR (Berlin: Ch. Links Verlag, 1999), 257-75. 
"imagined communities." 10 The revolutionary pathos or "upside-down" character of the festival should thus be understood as far from external to socialist society; rather, it proved inherent to the very conceptualization of the East German late socialist project. This rethinking of the festival sets in sharp relief the extent to which one of the East German state's ongoing challenges resulted from its own embrace of international socialism.

\section{Rethinking East German Socialism through a Postsocialist Lens}

This article draws on the work of postsocialist scholars to understand state socialism beyond the search for what Anna Krylova refers to as the "tenacious liberal subject" that dominates Western analyses of the Eastern bloc. ${ }^{11}$ The postsocialist approach is further germane for rethinking the public/private, official/unofficial, or authentic/inauthentic divides that borrow from Jürgen Habermas's notion of the "public sphere" and that remain central to liberal assessments of state socialism. ${ }^{12}$ To that end, the article deliberately replaces the idea of the public sphere with a focus on socialism's real and imagined public spaces. Public spaces might be understood as representing what Uta Staiger has referred to as "individual and collective configurations of subjectivity" that are "organized spatially and symbolically in the city through imaginaries invested in shared, public places." ${ }^{13}$ By tracing configurations of subjectivity across public spaces, we gain insights into how individuals not only imagined themselves as part of broader communities, but also into how they elided the "official versus unofficial" and "authentic versus inauthentic" divisions that scholars tend to inscribe onto state socialist projects.

This analytical reframing of socialist public space at the local level is further informed by postsocialist interventions concerning the problematic renderings of the Cold War globally. In her theorization of state socialism, Katherine Verdery argues that the Cold War produced "a form of knowledge and a cognitive organization of the world." As such, it laid down the "coordinates of a conceptual geography grounded in East vs. West [with] implications for the further divide between North and South." As Verdery goes on to note, "mediating the intersection of these two axes were socialism's appeal for many in the 'Third World' and the challenges it posed to the First [World]." ${ }^{14}$ Despite Cold War geopolitical divisions, individuals,

\footnotetext{
${ }^{10}$ Benedict Anderson, Imagined Communities: Reflections on the Origin and Spread of Nationalism (London: Verso, 2006). The concept "spatial imaginaries" draws on Henri Lefebvre, The Production of Space, trans. Donald Nicholson-Smith (Oxford: Wiley-Blackwell Publishers, 1991); Cornelius Castoriadis, The Imaginary Institution of Society, trans. Kathleen Blamey (Cambridge, MA: MIT Press, 1987); Geoff Eley, Nazism as Fascism: Violence, Ideology, and the Ground of Consent in Germany, 1930-1945 (New York: Routledge, 2013), 132-55.

${ }^{11}$ Anna Krylova, "The Tenacious Liberal Subject in Soviet Studies," Kritika: Explorations in Russian and Eurasian History 1, no. 1 (2000): 119-20. See also Andrew Zimmerman, "Foucault in Berkeley and Magnitogorsk: Totalitarianism and the Limits of Liberal Critique," Contemporary European History 23, no. 1 (2014): 225-36.

${ }^{12}$ Yurchak, Everything Was Forever, 14-22.

${ }^{13}$ Uta Staiger, "Cities, Citizenship, Contested Cultures: Berlin's Palace of the Republic and the Politics of the Public Sphere," Cultural Geographies 16, no. 3 (2009): 312. Staiger's approach is useful insofar as she uncouples the concepts of the public sphere and public space.

${ }^{14}$ Katherine Verdery, What Was Socialism and What Comes Next? (Princeton, NJ: Princeton University Press, 1996), 4. For a more recent take on the importance of adopting a theoretically informed framework to understand how the Second World supported Third World anticolonial movements, see Andrew Zimmerman, "Conclusion: Global Historical Sociology and Transnational History-History and Theory Against Eurocentrism," in Global Historical Sociology, ed. Julian Go and George Lawson (Cambridge: Cambridge University Press, 2017), 250.
} 
ideas, and cultural expressions did traverse both the East-West and North-South boundaries. International solidarity proved to be one vehicle for such transgressions, whereby the East German state intentionally brought the outside world into the German Democratic Republic (GDR). ${ }^{15}$ In turn, East German youths often viewed themselves as part of an international youth culture that cut across ideological and sociopolitical movements-from countercultural activities in the West, to solidarity networks with revolutionary actors, including the Vietnamese, Chileans, Palestinians, as well as Black Power groups, in the Atlantic World. ${ }^{16}$ It was, in this respect, that East German international solidarity embedded global lexicons of resistance, both real and imagined, in local public spaces during the 1973 Red Woodstock, with lasting repercussions well beyond the festival.

As a word of caution, we should be wary of idealizing East German imagined communities, especially since actual state-generated solidarity projects were mired in contradictions. Such inconsistencies emerged because the East German state reinforced the established demarcations between the East and West, as well as between the North and Southdespite its commitment to an antifascist and anti-imperialist agenda. Moreover, East German citizens also recognized their "East Germanness" against an "other" in ways that underscored negative conceptions of class, race, and sexual difference, all of which remained deeply embedded in the East German social fabric. ${ }^{17}$ In the postcolonial era, this phenomenon was not unique to East Germany; Western states engaged in their own "othering" processes. Yet, in the case of East German society, it was especially problematic, as it demonstrated the extent to which the state's proclaimed antifascist origins, as well as its anti-imperialist agenda, had serious limitations. The following discussion makes clear how youths, at times, reinforced, and, at other times, rejected the gendered, sexualized, and racialized tropes that remained intrinsic to the structuring of East German public spaces.

\section{A Brief History of the Socialist World Festivals}

The first World Festival of Youth and Students took place in Prague in 1947, with subsequent festivals occurring every other year through the mid-1960s, after which they became slightly less frequent. Transnational by nature, they were organized by two socialist-leaning, non-government organizations - the World Federation of Democratic Youth (WFDY) and the International Union of Students (IUS) - both of which supported international and national preparatory committees with the organization of events on the ground in locations as far-flung as Budapest, Helsinki, Havana, Moscow, and East Berlin. ${ }^{18}$ By the 1960s,

\footnotetext{
${ }^{15}$ Scholars of Cold War German history tend to focus on East-West connections at the expense of NorthSouth ones. Recent works that reject this binary include Patryk Babiracki and Austin Jersild, eds., Socialist Internationalism in the Cold War: Exploring the Second World (New York: Palgrave Macmillan, 2016); Quinn Slobodian, ed., Comrades of Color: East Germany in the Cold War World (New York: Berghahn, 2015).

${ }^{16}$ Timothy S. Brown provides an important framework for examining such transnational linkages in “"1968' East and West: Divided Germany as a Case Study in Transnational History," American Historical Review 114, no. 1 (2009): 69. See also Andrew Zimmerman and Katherine Pence, "Transnationalism," German Studies Review 35, no. 3 (2012): 495-500.

${ }^{17}$ Quinn Slobodian, "Introduction," in Slobodian, ed., Comrades of Color, 2.

${ }^{18}$ For an overview of the World Festivals and the role of the WFDY and IUS, as well as of the international and national preparatory committees, see Das Bundesbeauftragte für die Unterlagen des Staatssicherheitsdienstes (BStU), Ministry for State Security (MfS) HA II/13, Erwin Breßlein, "Die Weltjugend und der Dogmatismus. Geschichte und Problematik der Weltjugendfestspiele,” June 1973.
} 
the festival themes reflected the aspirations of the Soviet Union and, by extension, the Eastern bloc countries to forge connections with Third World state and non-state actors in the aftermath of the rapid wave of decolonization across the global South. In projecting international solidarity across time and space, the festivals came to embody a socialist ritual that travelled from one city to the next, collapsing the local versus global divide.

While a demonstration of socialism's internationalism was at least part of the impetus for the festival's mobile character, its ability to be rooted temporarily in local spaces also served a strategic purpose. East Berlin, for instance, represented a particularly important site for the festival, as it symbolized a key "border region" during the Cold War. ${ }^{19}$ This designation refers to the idea that the divided city of Berlin-located deep within the East German state- served as both a concrete and imagined point of interaction between the "East" and "West" during the Cold War. In fact, the World Youth Festival had been held once before in East Berlin - in 1951. ${ }^{20}$ At the time, the presence of international youths had undoubtedly served to reinforce the East German state's claim to legitimacy in the face of the West German state's refusal to recognize it. ${ }^{21}$ Countering West German isolation efforts, the 1951 festival program underscored the East German state's foundational myth, by aligning the GDR's proclaimed antifascist origins with a commitment to anti-imperialist struggles in the Third World. ${ }^{22}$

By contrast, the 1973 festival in East Berlin took place during a period of relaxation between the East and West. Rather than seeking to legitimize the GDR, state planners recognized the 1973 festival as indicative of the very spirit of détente that had come to mark the shift in East-West German relations after the recent signing of the Basic Treaty. That agreement had not only established "neighborly relations" between the two German states, but also paved the way for widespread recognition of the GDR beyond the Eastern bloc, ending the decades-long struggle for legitimacy that East and West Germany had fought through diplomatic and trade agreements in the Third World. As the West German weekly Der Spiegel reported, the 1973 festival seemed to embody "the openness, even opulence with which, this week, the GDR presented itself before the rest of the world and its own people." 23 Yet, despite East Germany's improved international standing, the preparations for the 1973 festival reflected the East German authorities' continued concern with perceived internal and external threats that were, in many respects, exacerbated-rather than diminished-by the relaxation in East-West tensions.

\footnotetext{
${ }^{19}$ For a discussion of divided Germany — rather than Berlin specifically — as " the border region of the Cold War," see Thomas Lindenberger, "Divided but Not Disconnected: Germany as a Border Region of the Cold War," in Divided, but Not Disconnected: German Experiences of the Cold War, ed. Tobias Hochscherf, Christoph Laucht, and Andrew Plowman (New York: Berghahn, 2010), 14.

${ }^{20}$ Andreas Ruhl, Stalin-Kult und Rotes Woodstock: Die Weltjugendfestspiele 1951 und 1973 in Ostberlin (Marburg: Tectum Wissenschaftsverlag, 2009).

${ }^{21}$ The West German policy of not recognizing countries that established relations with the GDR became known as the Hallstein Doctrine in 1955. See, e.g., William Glenn Gray, Germany's Cold War: The Global Campaign to Isolate East Germany, 1949-1969 (Chapel Hill: University of North Carolina Press, 2003).

${ }^{22}$ In both cases, they were fighting the "West." On East German solidarity, see esp. Toni Weis, "The Politics Machine: On the Concept of 'Solidarity' in East German Support for SWAPO," Journal of Southern African Studies 37, no. 2 (2011): 351-67.

23“Lesen Sie mal Marx, Herr Dutschke: Peter Brügge über die Deutschen beim Weltjugendfestival in Ost-Berlin,” Der Spiegel, Aug. 6, 1973.
} 


\section{The Grotesque Body between Everyday Life and the Festival Space}

In laying the groundwork for the festival, the state adopted measures aimed first and foremost at cleansing the East German capital of so-called "asocials" or "outsiders." According to Peter Stallybrass and Allon White, "outsiders are constructed by the dominant culture in terms of the grotesque body." Yet, as Bakhtin makes clear in his rendering of the medieval festival, "the grotesque body ... has its discursive norms too: impurity (both in the sense of dirt and mixed categories), heterogeneity, masking, protuberant distension, disproportion." 24 Such conceptions of outsiders were far from foreign to state socialism. In the months preceding the festival, East German authorities had sought to cleanse so-called asocial elements that had long laid claim to the East German capital. To achieve this end, the state adopted two specific measures: the criminalization and incarceration of "asocial," as well as other, citizens; and the reinforcement of the border regime through increased security measures designed to monitor the movement of "outsiders." The preparation for the festival thus assumed an internal logic rooted in the East German state's long-standing practice of seeking to purge the "grotesque" in order to achieve the optics of ideological conformity in public spaces.

Well in advance of the festival, the police forces and the Stasi coordinated efforts to remove so-called criminal youths, the mentally ill, and sex workers who lived in or frequented the city. ${ }^{25}$ The state arrested between 1,700 and 2,300 people, with many categorized as "asocials" and "hooligans"; roughly another 2,500 fell under increased surveillance. An additional 800 individuals found themselves banned from East Berlin in the months preceding the festival. ${ }^{26}$ The state also heightened security measures with the deployment of roughly 4,000 official and unofficial MfS personnel to prepare for the festival events. The East German Volkspolizei (People's Police, or VoPo) were assigned to monitor the streets of East Berlin, some wearing uniforms, others in plain clothes or in the blue shirts of the Freie Deutsche Jugend (Free German Youth, or FDJ). ${ }^{27}$ In addition, the state recruited members of the FDJ to support the security forces charged with maintaining order at the events. ${ }^{28}$

\footnotetext{
${ }^{24}$ Stallybrass and White underscore Bakhtin's distinction between the classical body as "inside," and the grotesque as "outside," societal norms. See Stallybrass and White, The Politics and Poetics of Transgression, 2223.

${ }^{25}$ See the police reports from June and July 1973, in Landesarchiv, Berlin (LAB), C Rep 303, 778, Berlin Presidium of the National Police. See also Thomas Lindenberger, "“Asociality' and Modernity: The GDR as a Welfare Dictatorship," Socialist Modern: East German Everyday Culture and Politics, ed. Katherine Pence and Paul Betts (Ann Arbor: University of Michigan Press, 2008), 211-33. During the 1951 festival, there had also been many arrests of so-called asocials. See Andrew I. Port, "When Workers Rumbled: The Wismut Upheaval of August 1951 in East Germany," Social History 22, no. 2 (1997): 145-73.

${ }^{26} \mathrm{LAB}$, C Rep 303, 616, “Abschlussbericht über die Erfüllung der Aufgaben zur Gewährleistung einer hohen öffentlichen Ordnung und Sicherheit anlässlich der X. WFS der Jugend und Studenten 1973 in der Hauptstadt der DDR, Anlage 5, Berlin," Aug. 7, 1973. Nearly seven thousand individuals across the GDR fell under investigation for violations of $\$ 249$ StGB in the first half of 1973 . See Wolle, Die heile Welt der Diktatur, 165.

${ }^{27}$ The festival corresponded with a general expansion of the Minstry for State Security under Honecker's rule. See John C. Schmeidel, Stasi: Shield and Sword of the Party (New York: Routledge, 2008); Mike Dennis, The Stasi: Myth and Reality (London: Pearson, 2003). On the Volkspolizei and its increased politicization, see Richard Bessel, "Establishing Order in Post-war Eastern Germany," Past and Present, 210, Issue Suppl. 6 (2011): 139-57.

${ }^{28}$ LAB, C Rep 303, 616, “Anlage 5, Berlin,” Aug. 7, 1973. The exact number of officers at the events is difficult to determine because of conflicting reports. For the claim that as many as four thousand FDJ Order Group members were summoned to Berlin for the festival, see Ohse, Jugend nach dem Mauerbau, 351.
} 
At the border checkpoints between East and West Berlin, East German authorities focused on halting the entry of so-called right-wing extremists, i.e., conservative West German youths, as well as "left-wing extremists," namely, Trotskyites and Maoists. They also confiscated materials that youths and other visitors attempted to smuggle into the festival. A Stasi report from July 30 noted, for example, that, in the midst of the festival, a couple of hundred "left-wing extremists" had attempted to travel across the Friedrichstraße train station from West Berlin to East Berlin. The individuals included members of the League against Imperialism and other communist groups from West Berlin, who planned to distribute pamphlets at the festival. They had concealed the materials beneath their clothes, especially below the waist and on their backs. Operating under the assumption that the border guards would target male individuals, they relied heavily on female members of the group to carry the pamphlets. In the end, many of the leftists were denied entry by GDR border guards; yet, as the report acknowledged, at least some of the individuals managed to make it through to distribute the pamphlets. ${ }^{29}$

Despite such heightened security measures, a steady stream of people and politically "subversive" materials did flow each day across the border into East Berlin. ${ }^{30}$ Indeed, as scholars have acknowledged, the East German state only succeeded to a certain degree in disciplining the people and the lived spaces they inhabited. ${ }^{31}$ The festival was certainly no exception. As the state opened up the "cleansed" city to hundreds of thousands of youths and visitors, those who occupied public spaces reimagined the socialist ideal in their own image, rendering it once again open to reinterpretation. The process began with the steady stream of bodies and subversive materials across the border, and it continued with individual and collective acts of performativity that participants carried out during the festival. ${ }^{32}$

To be sure, the East German authorities aimed to ensure ideological conformity among their own youths, introducing a GDR-wide educational program in the year leading up to the festival. ${ }^{33}$ Yet, international solidarity was not something that could be achieved through propaganda alone. Rather, it required a process of ritual embodiment via youth performances in festival activities — including the parades, rallies, meetings, and sporting events - that were to take place in East Berlin. The presence of hundreds of thousands of East German youths in

${ }^{29}$ BStU MfS ZAIG 11173, "Information: Aktivitäten linksextremistischer Organisationen gegen die X. Weltfestspiele von Westberlin aus," n.d.

${ }^{30}$ See the Stasi daily reports, including BStU, MfS 2180, "Information über Probleme und Vorkommnisse der Sicherheit und Ordnung," July 24-Aug. 6, 1973; "Information über verhinderte Störaktion linksextremistischer Kräfte," July, 30, 1973.

${ }^{31}$ For important early approaches to the limits of the GDR state's control, see, e.g., Richard Bessel and Ralf Jessen, eds., Die Grenzen der Diktatur: Staat und Gesellschaft in der DDR (Göttingen: Vandenhoeck \& Ruprecht, 1996); Detlef Pollack, "Die konstitutive Widersprüchlichkeit der DDR. Oder: War die DDR-Gesellschaft homogen?," in Geschichte und Gesellschaft 24, no. 1 (1998): 110-31; Konrad Jarausch, ed., Dictatorship as Experience: Towards a Socio-Cultural History of the GDR (New York: Berghahn, 1999). For a range of recent sociocultural and sociopolitical approaches to studying the GDR, see Mary Fulbrook and Andrew I. Port, eds., Becoming East German: Socialist Structures and Sensibilities after Hitler (New York: Berghahn, 2013).

${ }^{32}$ This concept of performativity builds on Judith Butler's work, as adopted in Yurchak, Everything Was Forever, 18-20.

${ }^{33}$ In the months leading up the festival, Junge Welt, for instance, featured daily propaganda that focused on education. See Stiftung Archiv der Parteien und Massenorganisationen der DDR im Bundesarchiv (SAPMO-BA), DY 24 7153, "Konzeption für die Arbeit von Presse, Rundfunk und Fernsehen der DDR in Vorbereitung der X. WFS der Jugend und Studenten," n.d. 
blue FDJ shirts reinforced the state's desire for a visual aesthetic of order through the collective assembly of their uniformed bodies. Yet, at the same time, it was the presence of international guests alongside East Germans that was essential for transforming the concrete East Berlin cityscape into the imagined international socialist ideal. As the official FDJ youth newspaper, Junge Welt, reported, delegations presented themselves with "colorful national costumes and clothes, balloons, flowers, giant banners, flags. Rhythmic dances with a genuine Latin American or African temperament enraptured the onlookers with true enthusiasm." 34 Such descriptions, alongside full-page collages of international youth in their traditional costumes, reflected the aesthetic of heterogeneity that the East German authorities sought to achieve during the festival.

This performative aspect of the solidarity discourse proved fundamental to the state planners' vision: in essence, international solidarity could only be realized through the diversity of the festival participants' bodies present in the festival space. In assessing earlier festivals, Quinn Slobodian refers to the state's carefully cultivated images of heterogeneity as "a mode of visual representation that could be called socialist chromatism." He goes on to note that, "within the larger idiom of socialist realism, socialist chromatism relied on skin color and other markers of phenotypic difference to create (overly) neat divisions between social groups within a technically nonhierarchical logic of race." 35 According to Slobodian, such images underscore the paradoxes of East German socialism insofar as the state claimed to erase difference, while reinforcing a process of "othering" in a "Saidian" sense, with the festival serving as a key representation of the socialist chromatic ideal. ${ }^{36}$ Yet, images of heterogeneity built on "(overly) neat" racial divisions become harder to trace when shifting from the stategenerated motifs of the festival to activities on the streets of the city. Somewhere along the way, the state discourse often became dislodged. This process occurred as the state agenda was appropriated, shifted, and ultimately transformed by those who engaged with it. ${ }^{37}$ While taking on a singular meaning in the state newspapers, socialist internationalism took on new connotations when international guests-such as Angela Davis or Yasser Arafat, who attended the festival as the heads of their respective countries' delegations - adopted it in their public appearances and speeches.

At the 1973 festival, Davis and Arafat represented both distinguished guests and the classic embodiment of the "other" that the state sought to celebrate, yet control. As a critical rereading of Bakhtin suggests, one encountered during the festival-like the carnival—a "mobile, conflictual fusion of power, fear and desire in the construction of subjectivity: a psychological dependence upon precisely those Others which are being rigorously opposed and excluded at the social level." 38 At the Red Woodstock there was a double-othering process at play, with both the cleansing of the internal subversive elements and the controlling of perceived external threats; yet, in turn, both used the heterogeneity of the festival to open up the solidarity rhetoric and public spaces through their embodiment of the festival ideal. Rather than rendering the

\footnotetext{
34“"Das ging los—das war riesengroß gestern im Stadion der Weltjugend,” Junge Welt, July 29, 1973.

${ }^{35}$ Quinn Slobodian, "Socialist Chromatism: Race, Racism, and the Racial Rainbow in East Germany," in Slobodian, Comrades of Color, 24.

${ }^{36}$ Edward Said, Orientalism (New York: Vintage Books, 1979).

${ }^{37}$ According to Weis, "the rhetoric of solidarity remained abstract enough to be filled with different contents,"; see Weis, "The Politics Machine," 352. He writes, however, that actual interactions between East Germans and non-East Germans remained minimal in everyday life.

${ }^{38}$ Stallybrass and White, Politics and Poetics of Transgression, 5.
} 
festival as authentic or inauthentic, their individual yet collective assertion of subjectivity enabled what one might refer to as diverse "imaginaries invested in shared, public places." 39

\section{Solidarity across Public Spaces: The Cases of Angela Davis and Yasser Arafat}

Beginning in the early 1970s, the East German state honored Angela Davis as a key spokesperson of the "other America" and as a powerful symbol of the Black Power movement. She became an icon in the GDR after her imprisonment in the United States on charges of having indirectly aided in an armed hold-up of a courtroom in California to free the "Soledad brothers": George Jackson, Fleeta Drumgo, and John Clutchette, who were accused of murdering a guard at Soledad prison. While Davis was incarcerated, the East German state organized exhibitions and campaigns, such as "One Million Roses for Angela Davis," with East German youths sending solidarity postcards and letters to the prison where she was being held. The East German leadership also placed pressure on the American judge who ruled on her case, reminding him that the international community would assess US race relations based on the outcome of the trial. When Davis was finally acquitted, the East German Socialist Unity Party (Sozialistische Einheitspartei Deutschlands, or SED) called the verdict a victory for the socialist solidarity cause..$^{40}$ Davis also recognized the importance of the international campaign, writing in her autobiography that her freedom had been secured through "nothing more and nothing less than the tremendous power of united, organized people to transform their will into reality." Shortly after her release, she travelled to the socialist bloc_-as well as to Cuba and Southeast Asia-declaring that "the international campaign had not only exerted serious pressure on the [US] government, it had also stimulated the further growth of the mass movement at home," i.e., in the United States. ${ }^{41}$

Davis certainly had limited control over how the East German authorities utilized her image in state-generated propaganda. As Katrina Hagen points out, one East German publication went so far as to fetishize her beauty and her "Afrika-Look," rendering Davis a symbol of the state's international solidarity campaign, which played up a "level of affect and desire as well as political conviction." ${ }^{22}$ Such exoticizing discourses reflected the GDR's deeper societal norms regarding the racialized and sexualized "other." 43 But it is important to avoid reducing Davis to a static symbol constructed through a flattened East German discourse on race and gender; rather, as seen during the festival, Davis willingly assumed the position at the head of the US delegation that travelled to the other side of the so-called Iron Curtain

\footnotetext{
${ }^{39}$ Staiger, "Cities, Citizenship, Contested Cultures," 312.

${ }^{40}$ Natalia Rasmussen, "Friends of Freedom, Allies of Peace: African Americans, the Civil Rights Movement, and East Germany, 1949-1989” (PhD diss., Boston College, 2014), 149-52. See also Sophie Lorenz, "Peace, Friendship, Solidarity'? East Germany and Angela Davis, 1965-1989," German Historical Institute Bulletin, Suppl. 8 (2012): 51-52.

${ }^{41}$ Angela Davis, An Autobiography (New York: Random House, 1974), 398. See also Davis's note of thanks to the citizens of the GDR, in "Die Kraft der Völker hat diesen Sieg errungen," Neues Deutschland, June 6, 1972.

${ }^{42}$ On the exoticized depictions of Davis in Für Dich magazine, see Katrina M. Hagen, "Ambivalence and Desire in the East German 'Free Angela Davis' Campaign," in Slobodian, Comrades of Color, 171-72.

${ }^{43}$ Sara Pugach, "African Students and the Politics of Race and Gender," in Slobodian, Comrades of Color, 131-34.
} 


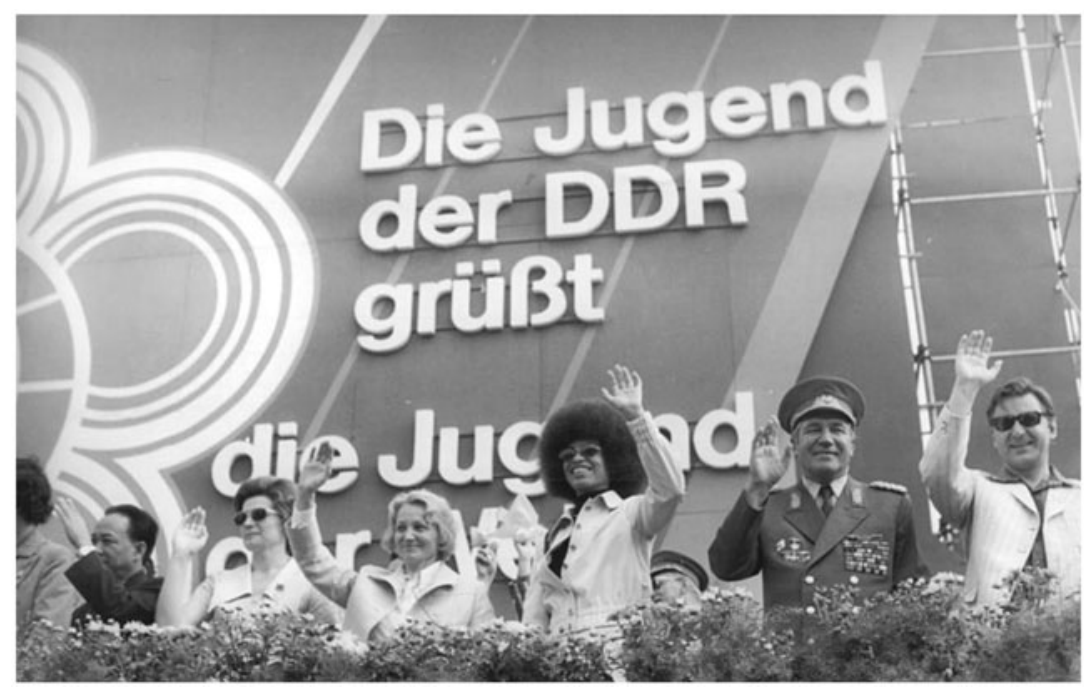

Fig. 1. Angela Davis, front and center, on stage at the 1973 festival. Source: Bundesarchiv, Bild 183M0804-0717 / Photo Credit: Dieter Demme.

to lay claim to a solidarity movement that had both local and global orientations. In turn, her participation at the Red Woodstock defined the very essence of the "pathos of a revolutionary ideal" that had come to dominate the festival spaces, reinforcing the East German state's international solidarity agenda, yet also subtly transforming it in her own image.

Over the years Davis had attended a number of socialist youth festivals. In her autobiography, she recalls her participation in the 1962 World Festival of Youth and Students in Finland, recounting vividly her awe at the Cuban revolutionaries:

It is not easy to describe the strength and enthusiasm of the Cubans. One event however illustrates their infectious dynamism and the impact they had on us all. At the end of their show, the Cubans did not simply let the curtain fall ... Those of us openly enthralled by the Cubans, their revolution and the triumphant beat of the drums rose spontaneously to join the conga line. And the rest - the timid ones, perhaps even the [CIA] agents - were pulled bodily by the Cubans into the dance... a dance brought into the Cuban culture by slaves dancing in a line of chains. ${ }^{44}$

Such personal experiences likely reinforced Davis's decision to serve as the head of the US delegation at the East Berlin festival in 1973, where she expressed her conviction that being in a socialist country surrounded by international youth would have a profound effect on the young delegates from the United States. Taking the microphone in Cafe Moskau, she proclaimed that this next generation of left-leaning youths would incite "new important initiatives of the anti-imperialist struggle." 45 The power of Davis's presence, coupled with her faith in the revolutionary potential of the younger generation, transformed what might have been a scripted rendering of solidarity at the official level into one that instead contained diverse interpretations, as well as competing subjectivities in the festival spaces. ${ }^{46}$

\footnotetext{
${ }^{44}$ Davis, An Autobiography, 123-24.

45 “Angela Davis: Festival ist ein historisches Ereignis," Junge Welt, Aug. 3, 1973.

${ }^{46}$ For the argument that the East German state agenda tempered Davis's revolutionary appeal, see Hagen, "Ambivalence and Desire," 173.
} 
On the final day of the Red Woodstock, Davis assumed the role of spokesperson for the festival youths, issuing an "Appeal to the Youth of the World" in which she declared: "We know imperialism. That is why we are strengthening our actions and our struggle, uniting our efforts and consolidating our cooperation, to make the pursuit of peace and social progress unstoppable ..." 47 Over the years, Davis had positioned herself as a powerful, unapologetic supporter of socialist solidarity, giving voice to a variant of it that instilled such rhetoric with elements of anti-imperialism, Black Power, and youth internationalism. In making the appeal, Davis was probably less concerned with legitimizing the GDR's solidarity agenda per se, than with projecting her message as it intersected with that of the socialist state. Having fought against the injustices of a system marked by social and racial inequalities in the United States, Davis recognized the importance of the East German solidarity cause; yet, she arguably also imparted a decidedly anti-statist revolutionary bent to the international socialist struggle. Despite the East German authorities' careful wording and even molding of Davis's image, the solidarity agenda might therefore be understood as having assumed multivalent meanings, as Davis and others expressed their own versions of it during the festival.

At the time of the events in East Berlin, many East German youths not only recognized Davis from the frequency of her image in state propaganda, but were also familiar with her affective force, thanks to her prior visits to the GDR. ${ }^{48}$ Davis had first made her way across the "Iron Curtain" in the late 1960s, during her time as a student in West Germany. After the end of her trial in 1972, she returned to the GDR, where she was granted an honorary degree from the Karl Marx University in Leipzig — an accolade similar to those that the East Germans had previously conferred on other American civil rights activists, including W. E. B. Du Bois, the cofounder of the National Association for the Advancement of Colored People, and Paul Robeson, an African American musician, actor, and activist. By the time of the 1973 festival, Davis was thus a familiar face to most East German youths, many of whom had written her letters, welcomed her at rallies, and listened to her speeches. In the years following the festival, Davis would return to East Berlin in 1975 to participate in the socialist World Congress of Women, which occurred in conjunction with the United Nations International Women's Year. When a delegation of African American editors and publishers visited the GDR that same year, one of them noted that Davis was recognized as nothing less than "a folk heroine by [East German] students because of her fight for the downtrodden." 49 This image was partially generated by East German state propaganda, but it was also a result of the revolutionary zeal that Davis herself expressed during her participation in the international solidarity events, the 1973 youth festival, and the 1975 women's congress.

Though less well-covered than Davis in the East German media (as well as in recent historical accounts), Yasser Arafat was a second prominent guest at the 1973 festival who

\footnotetext{
47 “Appell aus Berlin an die Jugend der Welt,” Junge Welt, Aug. 6, 1973.

${ }^{48}$ On one East German's fondness, as well as deep respect, for Davis, see Anke Pinkert, "Rethinking the Humanities through Teaching the Holocaust in Prison," Studies in Law, Politics, and Society 64 (2014): 50. While performing research for my dissertation (see note 1), I heard similar recollections in a number of interviews with former East Germans who grew up in the 1970s.

${ }^{49}$ Quoted in Maria Höhn and Martin Klimke, Breath of Freedom: The Civil Rights Struggle, African American GIs, and Germany (New York: Palgrave Macmillan, 2010), 139. See also Sophie Lorenz, "Heroine of the Other America," in The Routledge Handbook of the Global Sixties: Between Protest and Nation-Building, ed. Chen Jian et al. (New York: Routledge, 2018).
} 
bolstered, yet also laid claim to, the East German solidarity discourse through his and the Palestinian delegation's participation in the events. In the year preceding the festival, Arafat had established a working relationship with the East German authorities, turning to them for political, material, and military support for the Palestinian cause. Yet, his invitation to the 1973 festival proved to be a pivotal moment in solidifying East German ties to the Palestine Liberation Organization (PLO). In fact, Arafat used the occasion to discuss with SED leader Erich Honecker the opening of a PLO consular office in East Berlin, ensuring diplomatic relations between the GDR and his organization, as well as material support for the PLO, in the years to come. ${ }^{50}$ In an issue of Shu'un Filastiniya (Palestine Affairs) that came out just after the festival, Mahmoud Darwish pointed out that the "world is neither a single integrated unit, nor is it true that East is East and West is West. But we are part of an international revolutionary movement which has branches in both East and West ... Palestine went to Berlin with its own hands; it has achieved moral independence." ${ }^{51}$ As Darwish observed, the festival created both a real and symbolic space in which the Palestinians could amplify the demands of the PLO by operating within the East German state-generated solidarity network.

East German support for the Palestinian cause was not an unburdened act. Whereas the West German state had sought to reconcile with the Nazi past through reparation payments and support for Israel, the GDR instead provided material and ideological backing to the Palestinian struggle. This decision was partially geopolitical in nature, given the Cold War bipolar division of the world into opposing ideological camps. But it also came about through a whitewashing of the German past, with East German leaders saddling their West German counterparts with blame for Nazi atrocities, as the heads of a country that was the supposed successor to the Third Reich. For young East Germans, especially those who had been born after World War II, the narrative of East German self-exculpation concerning Nazis' crimes was coupled with state propaganda highlighting the GDR's support for Palestinian self-determination as part of its broader antifascist and anti-imperialist platform. ${ }^{52}$ For them, East Germany's solidarity agenda with the PLO was thus, at least to some extent, stripped of its encumbered historical significance and instead shaped through the state's proclaimed antifascist foundational myth.

East German youths expressed solidarity with the Palestinian cause in ways that may still have unsettled the East German authorities. For instance, an FDJ participant - in his easily recognizable blue shirt-was photographed in front of an Arabic banner that read "Struggle of the Youth," wearing a makeshift headscarf that resembled the traditional kefficeh. ${ }^{53}$ The East German's act of donning the keffiyeh involved an element of cultural appropriation:

\footnotetext{
50“"Arab Guerrilla Units Are Set to Establish East Berlin Office,” New York Times, Aug. 19, 1973. See also Jeffrey Herf, Undeclared Wars with Israel: East Germany and the West German Far Left, 1967-1989 (New York: Cambridge University Press, 2016), 198-200.

${ }^{51}$ Mahmoud Darwish, "Yasser Arafat in Berlin," Journal of Palestine Studies 3, no. 1 (1973): 168.

${ }^{52}$ In the early phases of preparation for the festival, the East German leadership underscored a national program founded on the idea that, "after the defeat of Hitler's fascism by the glorious Soviet Army, ... the citizens of the GDR, under the leadership of the SED, designed the historic alternative to the imperialist Federal Republic on German soil." See SAPMO-BA DY24, 7123, "Kulturpolitische Grundkonzeption für das Nationalprogramm der DDR zu den X. WFS der Jugend und Studenten 1973 in Berlin,” Feb. 22, 1972. See also Jeffrey Herf, Divided Memory: The Nazi Past in the Two Germanies (Cambridge, MA: Harvard University Press, 1997), 33-35, 110-12; idem, Undeclared Wars with Israel, 198-200.

${ }^{53}$ The banner was likely carried by Palestinian youths associated with the PLO.
} 
Arafat had begun wearing the well-known, black-and-white patterned keffiyeh in the 1960s, transforming it into a symbol of Palestinian resistance against the Israeli state. The keffiyeh subsequently gained international appeal, particularly among Western leftists who supported the PLO. Yet, despite being appropriated as a symbol that took on a somewhat Western, stylized affect, it nonetheless remained a visceral reminder of the revolutionary zeal of the Palestinian cause. For East German authorities, both aspects were likely viewed as somewhat antithetical to the state-socialist agenda.

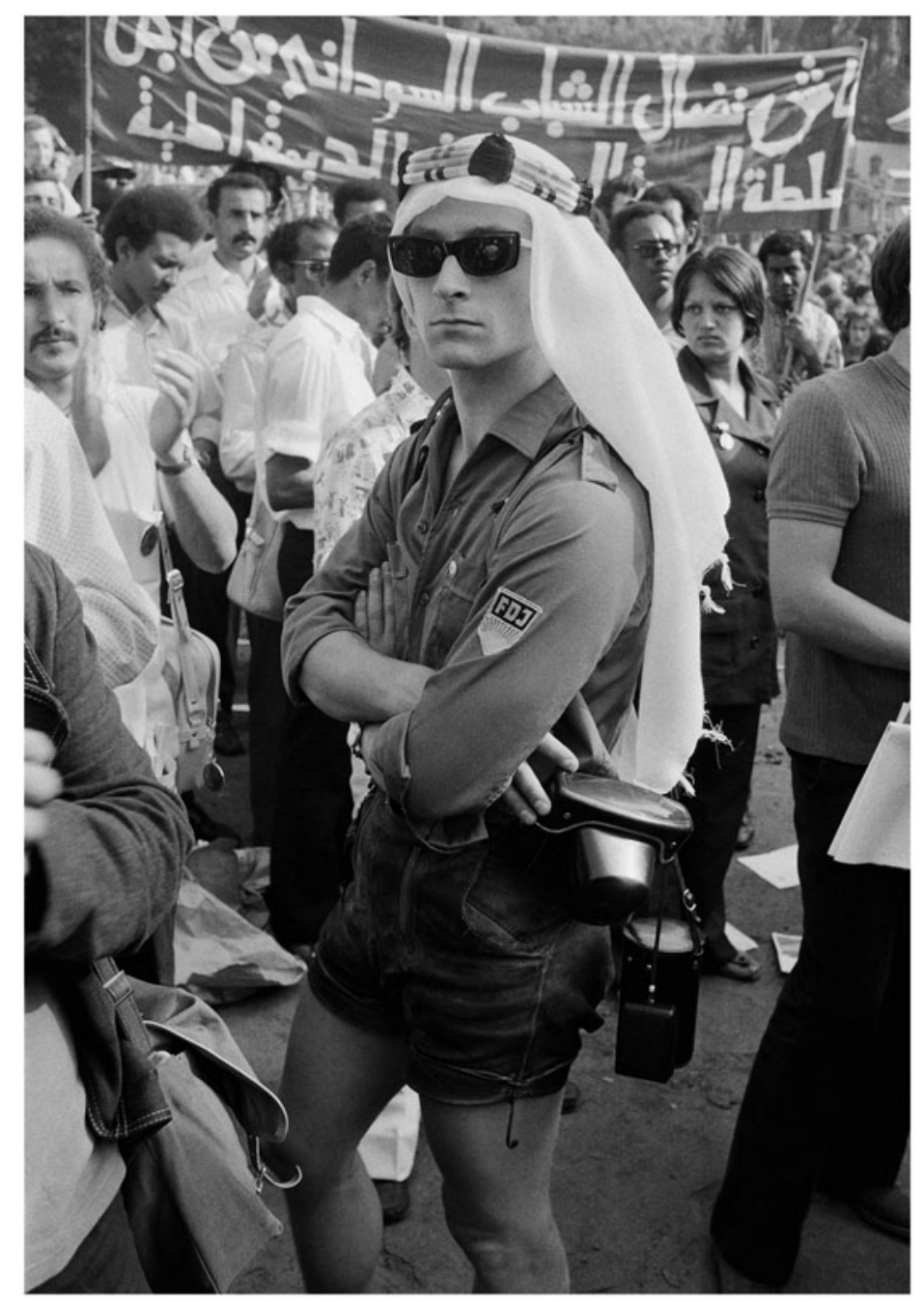

Fig. 2. Youths on Alexanderplatz during the 1973 festival. Source: German Historical Museum Nr. 2011 165 / Photo Credit: Thomas Hoepker, Magnum Photos.

At the time, East German authorities were especially wary of the more violent factions of the Palestinian movement. In the lead-up to the festival, they had taken measures to avoid a possible terrorist attack by the Black September Organization (a breakaway militant faction of the Palestinian organization, Fatah), similar to the one the group had carried out during the 
1972 Olympics in Munich. ${ }^{54}$ As a result, Palestinians travelling to the 1973 festival faced increased security at the border crossings, and those already in the GDR were placed under heightened surveillance. ${ }^{55}$ Given the Stasi's acute fear of Palestinian militant activities-as well as the SED's general concern with the potential radicalization of East German young people - the East German youth's donning of the keffich may have thus been read as a performative act that teetered on the edge of the subversive. But relations between the PLO and the East German state had become increasingly beneficial for both sides by the beginning of the 1970s. For the East Germans, the connection was important because Arafat had positioned the Palestinians within the broader anti-imperialist movement of the Third World, aligning the PLO with other revolutionary struggles, from Vietnam to Algeria. As a result, the PLO cause fit well with the East German state's solidarity agenda, not least because the Chinese were, at the time, also vying for influence in the Middle East and Africa. ${ }^{56}$ Arafat, in turn, condemned the 1972 incident in Munich and similar acts of terrorism, declaring that the "Palestinian people will fight with political, military and ideological and other methods, but are not prepared to engage in such senseless actions as hijacking of aircraft." 57 Regardless of whether Arafat could deliver on such promises, he clearly hoped to allay the fears of the East German leadership by rejecting the violent tactics of the Black September Organization and by reaffirming his commitment to strengthening relations with the GDR.

The East German youth donning the keffich was likely unaware, however, of the nuances of Cold War geopolitical developments; rather, the decision to put on the headscarf may have simply reflected the shifting subjectivities that young people assumed at the festival. In placing it on his head, he was not necessarily engaging in an act of open rebellion, but rather expressing a spontaneous act of solidarity that reflected the festival's spirit of cultural-political exchange. In fact, during the festival, over sixty thousand youths participated in a statesponsored rally in support of the Palestinian cause and peace in the Middle East. ${ }^{58}$ Such acts of solidarity did not exist alongside the official agenda of the East German state, but rather through it, since the two were intrinsically linked. In the years following the festival, such acts would take on alternative expressions, connecting East German subjecthood to

\footnotetext{
${ }^{54}$ The Black September Organization had taken Israeli athletes and a police officer hostage during the Munich Olympics, demanding the release of imprisoned Palestinians and members of the West German Red Army Faction. See Herf, Undeclared Wars with Israel, 161; Kay Schiller and Christopher Young, The 1972 Munich Olympics and the Making of Modern Germany (Berkeley: University of California Press, 2010).

${ }^{55}$ Kay Schiller, "Communism, Youth, and Sport: The 1973 World Youth Festival in East Berlin," in Sport and the Transformation of Modern Europe: States, Media, and Markets, 1950-2010, ed. Alan Tomlinson, Christopher Young, and Richard Holt (New York: Routledge, 2011), 63.

${ }^{56}$ Paul Chamberlin, "The Struggle Against Oppression Everywhere: The Global Politics of Palestinian Liberation," Middle Eastern Studies 47, no. 1 (2011): 30-33. The geopolitical struggle for the Third World heated up between the Soviets and the Chinese after the Sino-Soviet split, with the Soviets (and, by extension, some of the Eastern bloc countries) "adopt[ing] the Chinese revolutionary agenda to a significant degree." See Jeremy Friedman, Shadow Cold War: The Sino-Soviet Competition for the Third World (Chapel Hill: University of North Carolina Press, 2015), 14.

57 “In unserem [gerechten] Kampf stehen uns viele gute [Freunde] zur Seite," Neues Deutschland, July 31, 1973. A translated version of the article was circulated in a US Bureau of European and Eurasian Affairs memorandum. See the unclassified document, "Arafat at World Youth Festival," on WikiLeaks Public Library (https://wikileaks.org/plusd/cables/1973BERLIN01316_b.html).

58 "Ruf nach Frieden im Nahen Osten," Junge Welt, July 31, 1973.
} 
youth internationalism via campaigns that continued to lay claim to the East German solidarity agenda, but in ways that subtly shifted or transformed it from the inside out.

The East Germans had welcomed Davis and Arafat in particular because they reinforced the state's international solidarity agenda at the festival; they were not, however, the only ones playing this role. During the Red Woodstock, East German authorities highlighted a number of other specific causes that would continue to play a central role in the GDR's ongoing solidarity agenda. For instance, the GDR honored participants from both North and South Vietnam as distinguished guests; the US retreat from the war in Vietnam served more generally as a cause for much celebration. Participants from around the world took part in a campaign to raise funds for the Kinderkrankenhaus Nguyen Van Troi, a children's hospital in Vietnam, further demonstrating the continued commitment that the socialist state intended to provide to the Vietnamese. ${ }^{59}$ In the months following the festival, the GDR would turn its attention to other solidarity causes, with a heightened focus on supporting Chileans targeted by the right-wing military junta that brought Augusto Pinochet to power in Chile in September 1973. The campaign resonanated among many East German youths, not only as a result of the socialist state's propaganda, but also because a large delegation of Chileans had attended the 1973 festival, just weeks before the coup took place. ${ }^{60}$

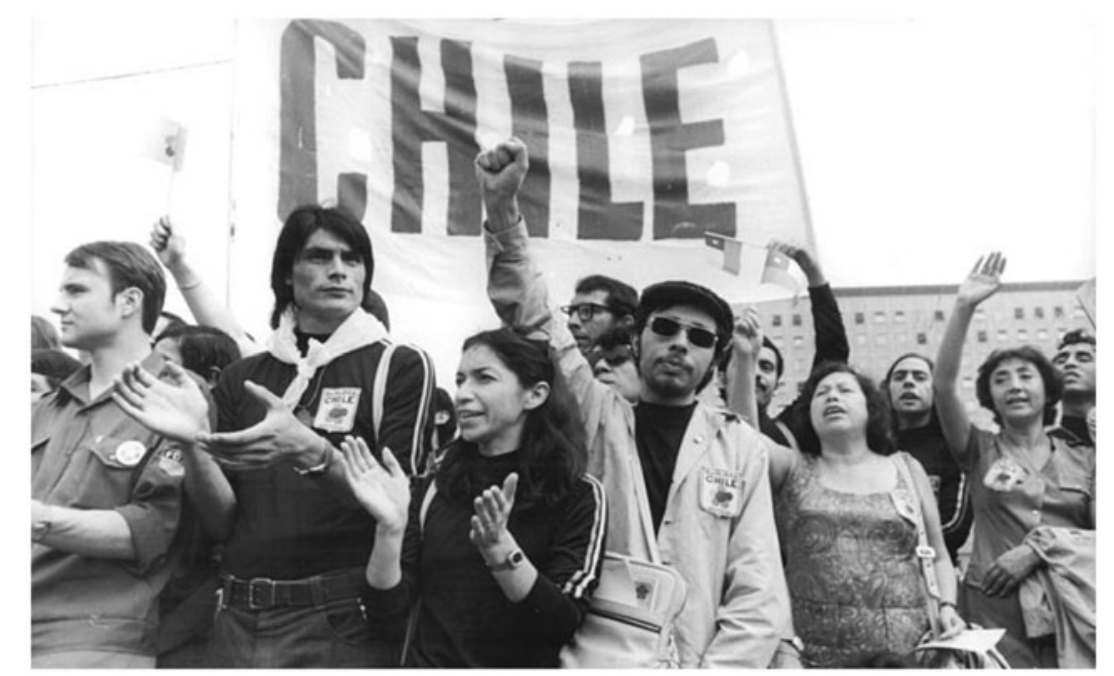

Fig. 3. Chileans at the 1973 Festival. Source: Bundesarchiv Bild 183-M0804-0760 / Photo credit: Jürgen Sindermann.

\footnotetext{
${ }^{59}$ SAPMO-BA, DY 24, 7157, Teil 1, “Pressebulletin,” July 30, 1973.

${ }^{60}$ Gladys Marín led the Chilean delegation at the festival. Gisela Steineckert, who later become the president of the GDR's Komitee für Unterhaltungskunst (Committee for Entertainment Arts), wrote a letter in Junge Welt that highlighted the anxiety that East German young people had felt for Marín and other festival participants from Chile, who had returned to their country just before the Pinochet coup. See "Sei willkommen-nimm unsere Liebe entgegen," Junge Welt, July 17, 1974. In the aftermath of the coup, Marín and other imprisoned Chilean communists received a flood of postcards from East German youths, who painted flowers and sent written notes to her. See, e.g., Luis Corvalán in der sozialistischen DDR zu Gast-Venceremos (Dresden: Verlag Zeit im Bild, 1977).
} 
The East German state also supported a number of anti-colonial revolutionary movements in the festival program as part of its ongoing solidarity activities, including a powerful campaign against the apartheid regime in South Africa. East German support for the African National Congress (ANC) and the South West African People's Organization (SWAPO) had begun in the 1960s with the establishment of the GDR solidarity committee, which sought to foment international opposition to the South African apartheid regime. The ties were strengthened during the 1973 festival, as representatives of the ANC and SWAPO made their way to East Berlin after attending a Pan-African Student Congress in Tunis in mid-July. Junge Welt reported that, at the end of the Congress, over one thousand African youths had flown directly to East Berlin to attend the Red Woodstock festival. ${ }^{61}$

Such connections conformed to the East German socialist international ideal; yet, they also produced lexicons of resistance that proved problematic for the East German state. This could be seen, for instance, in the list of demands that members of the Pan-African youth group delivered to the festival committee, including the guarantee that all countries that pursued a policy of apartheid or imperialism - with specific reference to South Africa, Rhodesia, and Israel-be banned from the festival. Directly challenging East German authorities, the Pan-African youths further threatened to boycott the events-especially if Chinese communist youths were not allowed to participate. East German authorities assured them that representatives of "racist regimes" would not be in attendance; yet, they obfuscated on the latter demand, noting that it was up to the Chinese to decide whether they would participate. ${ }^{62}$ The boycott was averted, but such groups succeeded in highlighting their alternative solidarity agendas within the very same public spaces where the 1973 festival events took place. In the following years, the GDR would maintain ties to PanAfrican youths, as well as to the ANC and SWAPO movements, as part of its broader solidarity agenda, largely by providing material aid and instituting solidarity campaigns for their causes. To some extent, the groups' international and, at times, revolutionary ideals would thus remain embedded in the East German solidarity agenda well after the Red Woodstock had ended.

\section{Socialist Ritualized Culture between the Carnivalesque and the Everyday}

In between the staged events, Alexanderplatz assumed the role of a leisurely meeting place for young people from around the world. In casting it as such, the East German state aimed to achieve a confluence between the political and cultural elements of the festival, as well as between the official and the unofficial spheres of youth exchange. According to the Chicago Tribune's foreign correspondent in Bonn, "The center of Berlin resembles a giant amusement park these days. Thousands of young people of all races and colors mill [through] the main [thoroughfares,] from which all traffic has been banned. Brass bands and beat groups are playing, and choirs are singing." 63 Laying claim to the space, young

\footnotetext{
61“FDJ auch in Zukunft an der Seite Afrikas," Junge Welt, July 19, 1973; "Grüße [von Tunis] an die Gastgeber," Junge Welt, July 26, 1973.

${ }^{62}$ SAPMO-BA, DY 24 22450, “Afrikanische Jugend droht mit Boykott des 10. WFS” (translation from IIEE-Bulletin, Jan. 26, 1973). Chinese youths did not attend the festival because of tensions between the Soviet Union and the People's Republic of China following the Sino-Soviet split.

63،E. Berlin Turns Best Face to the Youth Festival Throngs," Chicago Tribune, Aug. 3, 1973.
} 


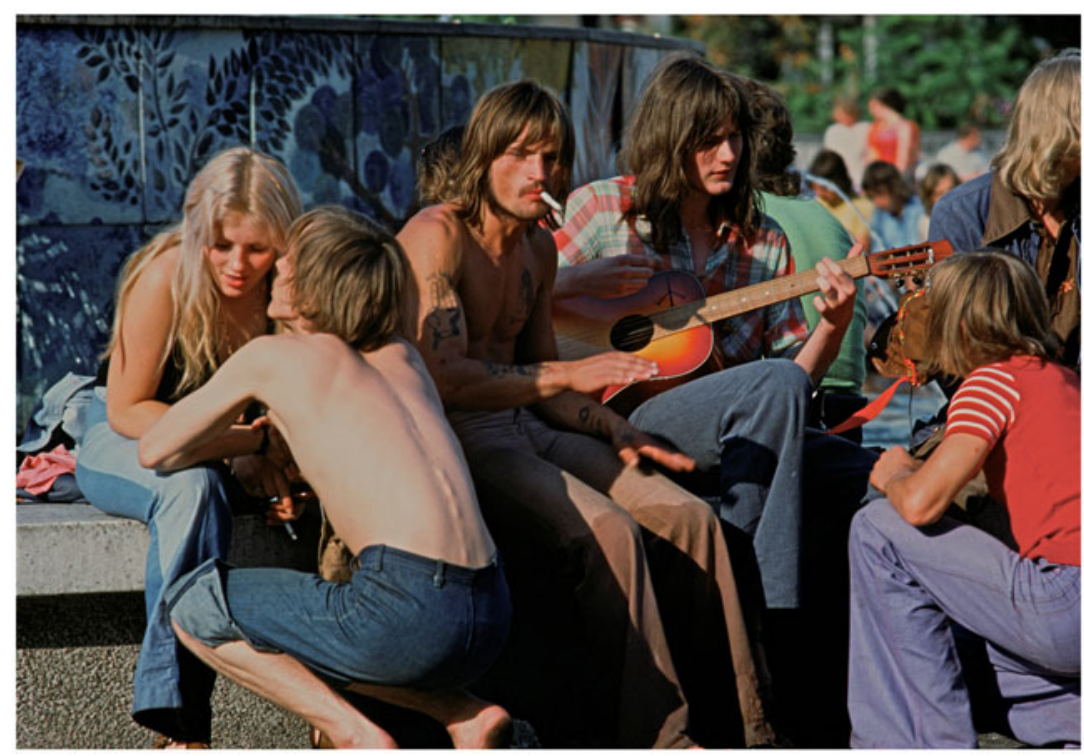

Fig. 4. East German Youth at the Festival. Source: German Historical Museum Nr. 2011-155 / Photo Credit: Thomas Hoepker, Magnum Photos

people congregated around the fountains, conversing, playing music, and drinking late into the night. The East German Press Bulletin reported that "the image, offered by the bright sunshine flooding Alexanderplatz on this day, was for the old Berliners without comparison[:] tightly packed, in small and large groups discussing and gesturing together, certain freely-spoken discussions, friendliness and cheerfulness..." ${ }^{64}$ This was not by accident, but rather by design: East German authorities recognized that the festival could only live up to their idealized images of solidarity's heterogeneity through the creation of an atmosphere that seemed somewhat conducive to open and uninhibited youth interaction. ${ }^{65}$

To that end, the East German leadership intentionally integrated popular youth rituals into the festival program in order to appeal to young people's shared interests and desires. For instance, the festival planners transformed Alexanderplatz into an open-air stage for rock concerts, in addition to more traditional folk music. Their focus on popular youth genres reflected the fact that the SED had taken decisive measures in the previous years toward integrating youth "dance music" into the state cultural agenda, with the relaxing of sanctions against Western artists and the opening of discos throughout the GDR. ${ }^{66}$ The state's embracing of popular music went back to the 1950s and 1960s; however, this had been a slow process involving moments of heightened repression. In December 1965, for

\footnotetext{
${ }^{64}$ SAPMO-BA, DY 24 7157, Teil 1, "Pressebulletin," July 30, 1973.

${ }^{65}$ The festival committee developed the idea of Alexanderplatz as a central meeting place for young people. See SAPMO-BA DY 24, 7176, "Entwurf: Konzeption 'Alexanderplatz der Weltjugend-rund um die Weltzeituhr,"” April 25, 1972.

${ }^{66} \mathrm{LAB}$, C Rep 104, 2137, "Anlage-Bericht über den Stand der Realisierung der Konzeption des Ministeriums für Kultur für die vorrangig zu lösenden Aufgaben bei der Gestaltung des kulturellen Lebens der Jugend in Vorbereitung der X. Weltfestspiele der Jugend und Studenten 1973 in Berlin," April 24, 1973.
} 
example, the SED attempted to crack down on beat and rock music at the Eleventh Central Committee Plenum, declaring the decision necessary to curtail "American immorality and decadence." 67 Yet, by the early 1970s, authorities had come to recognize that such measures had proven largely futile. When Erich Honecker became head of the East German leadership in 1971, the state adopted a new path, embracing youth music more openly. ${ }^{68}$

Around this time, the FDJ began promoting East German song groups and organizing music festivals. In founding a broader Singebewegung (song movement), the FDJ established the official October [Song] Club, which was created out of the informal, Berlin-based Hootenanny Club of young musicians. Beginning in the 1970s, East Germany also began hosting annual, state-sponsored Political Songs festivals, inviting performers from around the world to the GDR to play music with a decidedly political bent. The FDJ, for its part, sponsored the organization of thousands of amateur groups in the GDR to write and perform political music for festivals that conformed to state-socialist ideals. As MarcDietrich Ohse has suggested, "The song movement represented a compromise between the needs of the East Berlin leadership for a minimum degree of cultural autonomy and the internationalization of youth culture." 69 In other words, the movement was a site of negotiation between the authorities, who wanted to control the influence of Western music, and youths, who gravitated to it for various reasons. In 1973, the former planned to have East Germany's annual Political Songs festival coincide with the Red Woodstock, organizing performances, workshops, discussions, and open-air concerts that brought into the open the tension between the authorities' attempt to create state-controlled music events and the participants' desire to use music for their own purposes.

For East German authorities, music remained much less a manifestation of individualistic artistic expression than a political weapon that could be utilized to fashion a consciously socialist - as well as internationalist - citizenry. The West was seen to have taken advantage of music's ability to stir dissent among East German youths in the 1960s; in response, GDR authorities were now attempting to curb such influences, even repurposing them for their own ends. In the opening days of the festival, Junge Welt made clear, "The Song Festival is not a gala show, but rather a coming together of people, who play songs and sing about their daily struggles."70 East German authorities had carefully selected performers based on whose music would forward the international solidarity agenda. In total, over one hundred groups and soloists from forty-five countries were invited to participate, including Miriam Makeba from South Africa, Canzoniere Internazionale from Italy, Taoné Manguaré from Cuba, and Inti-Illimani from Chile. In addition, West German bands such as Floh de Cologne and Lokomotive Kreuzberg were featured on the

\footnotetext{
${ }^{67}$ Uta Poiger, Jazz, Rock, and Rebels: Cold War Politics and American Culture in a Divided Germany (Berkeley: University of California Press, 2000), 216.

${ }^{68}$ Peter Wicke, “Rock 'n' Roll im Stadtpark. Von einer unerlaubten Vision in den Grenzen des Erlaubten" in Jeans, Rock und Vietnam: Amerikanische Kultur in der DDR, ed. Therese Hörnigk and Alexander Stephan (Berlin: Theater der Zeit, 2002), 67-68. On the evolution of rock music, see also Ohse, Jugend nach dem Mauerbau; Mark Fenemore, Sex, Thugs, \& Rock ' $n$ ' Roll: Teenage Rebels in ColdWar East Germany (New York: Berghahn, 2007); Poiger, Jazz, Rock, and Rebels; Michael Rauhut, Rock in der DDR, 1964-1989 (Bonn: Bundeszentrale für politische Bildung, 2002).

${ }^{69}$ Ohse, Jugend nach dem Mauerbau, 144.

70 "Viel Beifall für Lieder und ihre Interpreten," Junge Welt, July 30, 1973.
} 
program. ${ }^{71}$ Most of the groups comprised self-proclaimed leftists, as well as representatives of international resistance movements; yet, as we will see, their music opened up both the lexicon and the performative aspects of the East German solidarity discourse, demonstrating its universality as well as its malleability.

As the authorities anticipated, the West German agitprop band Floh de Cologne drew large crowds to its performance. Floh was made up of a group of musicians who supported the West German Communist Party (DKP), which formed in the late 1960s, filling the void of the former Communist Party of Germany (KPD) outlawed in 1956. In contrast to many other beat and rock groups in the West, the group's music was overtly political. As Timothy Brown has pointed out, "Floh's performances tended to feature less 'songs' per se than political rants spoken or shouted over musical grooves." 72 In its manifesto, the group declared that "we use pop music as a transfer-instrument for our political texts. We take this to be more effective than, for example, lectures."73 In the late 1960s and early 1970s, the band was popular among both East and West German youths; even SED leaders approved the group's music, especially since it had released an album in 1968 condemning the war in Vietnam.

An East German documentary of the 1973 World Festival captured images of Floh on stage on Alexanderplatz, comparing socialism in the GDR to capitalism in the West. The group's catchy lyrics contained a degree of irony, highlighting companies and other things forbidden by the East German state that supposedly did so little for the West German working class: "In the GDR, however, almost everything is forbidden, Deutsche Bank, Dr. Oetker, Gunter Sachs, Helmut Horten, Jacqueline Onassis, and many other things that the workers need for everyday life ...," as well as "hospital charges, rent increases, teacher shortages, accumulation of wealth in employer hands ... and everything else that makes capitalism so attractive for the workers."74 Floh's criticism of West German capitalism through the lens of the East German's "forbidden society" was powerful, particularly because West Germans themselves, who were fed up with inequalities at home, were articulating it. But Floh's lyrics also implicitly acknowledged the forbiddenness that fueled dissent in "real existing socialism." This double meaning was likely not lost on young East Germans, who coveted many Western goods in their everyday lives-goods that remained forbidden or unavailable in the GDR.

The West Berlin group, Lokomotive Kreuzberg, staged a similar "Politrock" (political rock) performance during the festival. Hailing from the West Berlin countercultural scene that had its roots in the district of Kreuzberg, just on the other side of the Berlin Wall, Lokomotive also used rock music as a vehicle of social criticism. At the festival, they performed the rock-and-roll theater piece "James Blond: In Pursuit of the Wage Robbers," a parody about a secret agent disguised as a worker, who was pursuing a case of wage robbery. Junge Welt praised the group's eclectic performance for combining a number of

\footnotetext{
${ }^{71}$ Ibid. See also Sarah Jost, "'Unser Lied ist unser Kampf-Das Festival 'Politische Lieder zu den X.,"” Kulturation: Online Journal für Kultur, Wissenschaft und Politik 2 (2003) (http://www.kulturation.de/ ki_1_thema.php?id=42).

${ }^{72}$ Timothy S. Brown, "Culture, Class and Communism: The Politics of Rock in the West German 1968," Twentieth Century Communism 9 (2015): 77.

${ }^{73}$ Ibid., 77.

${ }^{74}$ Floh's performance is partially captured in "Wer die Erde Lebt," directed by Uwe Belz et al. (Berlin: DEFA-Studio für Dokumentarfilme, 1973).
} 
genres, from rock-and-roll to blues and beat, coupled with provocative anticapitalist lyrics that served as a form of "political agitation" that "got under one's skin."75 Their inclusion in the festival program undoubtedly set the precedent for invitations to other West German political rock bands in the following years, especially after the establishment of the East German "Rock for Peace" program in the 1980s. For example, the well-known West German musician Udo Lindenberg, among others, would be invited to perform at a peace concert in the GDR in 1983; unlike the earlier performances, however, Lindenberg would generate unrest among youths and provoke the ire of the authorities by speaking out more openly against the policies of the East German state. ${ }^{76}$

During the 1973 festival, neither Floh's nor Lokomotive's lyrics proved all that problematic for the authorities. Rather, it was the uninvited actors, such as East German dissidents, who launched a more open critique of the East German state by using the political song as a vehicle of protest against state socialism. In the months preceding the festival, East German singer and songwriter Wolf Biermann had submitted a piece to the Political Songs forum, which the authorities refused to include in the festival's program. Biermann-who was blacklisted at the time because of his overtly oppositional music - nonetheless decided to take advantage of the relaxed atmosphere on Alexanderplatz to play the song anyways. He later amusingly recollected the scene as one in which East German youths, as well as others from around the world, had created an organic space near the Weltzeituhr (World Clock) for him to perform, with the Stasi unable to break through to stop him. ${ }^{77}$

Creating his own makeshift stage on Alexanderpaltz, Biermann played a rendition of "Comandante Che Guevara," in which he paid homage to Che, with a red star on the breast of his jacket and a cigar resting on his lips, as an icon of revolutionary socialism. ${ }^{78}$ By the late 1960s, Che had become an internationally recognized symbol, elevated to martyr status for the socialist cause. His name was synonymous with resistance, usually against capitalism, but occasionally, as in the case of Biermann's song, he represented a symbol of revolutionary purity that could be directed against state socialism as well. Biermann used the political song to launch a leftist critique of the East German state in the very language of international solidarity that the state was espousing. In doing so, he effectively drew on an alternative conceptualization of socialist internationalism that elevated Che as a true revolutionary-in contrast to the functionaries of the GDR. His performance resulted in not only a stretching but also open subversion of the state's anti-Western solidarity discourse through its anti-statist depiction of Che. ${ }^{79}$

In an infamous crackdown by the East German state, Biermann was later expatriated in 1976, while performing on tour in West Germany. Scholars and activists alike have

\footnotetext{
75 “Lohnräubern auf der Spur,” Junge Welt, Aug. 1, 1973.

${ }^{76}$ Lorenz Lüthi, "How Udo Wanted to Save the World in 'Erich's Lamp Store': Lindenberg's Concert in Honecker's East Berlin, the NATO Double-Track Decision and Communist Economic Woes," Contemporary European History 24, no. 1 (2015): 83-103. On the ban on Western performers following an altercation with the West German band BAP, see Rauhut, Rock in der DDR, 97-98.

${ }^{77}$ BStU, MfS ZOS 1173, "Zentral Ablage-X WFS 'Banner'. Provokatorisches Auftreten von BIERMANN [unclear date]. See also "Wolf Biermann: Weltjugendfestspiele 1973 in Ostberlin” (https://www.youtube. com/watch?v=zkMzoWuNmTo).

${ }^{78}$ Ibid.

${ }^{79}$ In a conversation reprinted in Junge Welt, an FDJ member attempted to explain the nuances of East Germans' support for Che's "revolutionary engagement," while taking issue with his "theory of spontaneity" (Spontaneitätstheorie). See "Unser Alex ist nur ein Zeichen," Aug. 4, 1973.
} 
pointed to this as a turning point away from the early years of liberalization under Honecker's authority. ${ }^{80}$ Yet, it is nonetheless important to contextualize Biermann's performance on Alexanderplatz within the East German state's broader shift toward a ritualization of the political song-one that would have lasting repercussions well beyond the events of the festival. As David Robb has suggested, political songs continued to serve as "a popular and important cultural force" that remained a youth ritual in the GDR until 1989: "the attraction for many fans lay in the singers' exploitation of a basic contradiction within the GDR cultural policy. On one hand the political song was nurtured at an official level as a proudly coveted Erbe of revolutionary tradition. On the other hand, it was constantly viewed with suspicion due to its potential as a means of subversion." 81 Biermann, among others, embraced solidarity in the name of socialist internationalism - just not in the way the state had intended. His political critique using the imagery of the Third World icon Che Guevara demonstrated the extent to which competing conceptions of socialist internationalism were becoming endemic to the East German solidarity project by the 1970s. This was apparent as the hundreds of thousands of youths and other visitors who descended upon East Berlin reimagined the socialist ideal, rendering it once again "grotesque" (to draw on Stallybrass and White), as they opened it up to include alternative meanings - and their own vision of international solidarity.

\section{Performing Non-Normative Expressions of Gender and Sexuality on Alexanderplatz}

Embodying the atmosphere of the original American Woodstock festival, young people also engaged in nonnormative expressions of gender and sexuality that were forged, once again, through a negotiation of the East German solidarity agenda and the competing subjectivities of the young people in attendance. To that end, gender and sexuality functioned as both sites of control by the East German state and of resistance by East German citizens and international guests. In the lead-up to the festival, the East German state had sought in various ways to limit what it deemed to be sexual "transgressions": by removing sex workers and "subversive" youths from the festival venue, and by turning back others at its borders. At the same time, state propaganda at the festival embraced certain expressions of sexual emancipation-such as public nudism. As Josie McLellan has argued, "nudism was an important and highly visible part of the East German sexual revolution," particularly because East Germans had won a hard-fought struggle against the SED for the right to a Freikörperkultur ("free-body culture") over the previous decades. ${ }^{82}$ The state's acceptance of "free-body culture" was apparent, for instance, in the July 1973 edition of the East German monthly publication, Das Magazin, which featured a cover sketch with women of diverse ethnicities swimming together naked in a pool. ${ }^{83}$ The image reflected East

\footnotetext{
${ }^{80}$ Andreas Glaeser, Political Epistemics: The Secret Police, the Opposition, and the End of East German Socialism (Chicago, IL: University of Chicago Press, 2011), 481-82. On the Biermann affair more generally, see Fritz Pleitgen, ed., Die Ausbürgerung: Anfang vom Ende der DDR (Berlin: Ullstein, 2001).

${ }^{81}$ David Robb, "Political Song in the GDR: The Cat-and-Mouse Game with Censorship and Institutions," in Protest Song in East and West Germany since the 1960s, ed. David Robb (Rochester, NY: University of Rochester Press, 2007), 227.

${ }^{82}$ Josie McLellan, Love in the Time of Communism: Intimacy and Sexuality in the GDR (Cambridge: Cambridge University Press, 2011), 144.

${ }^{83}$ See the cover of Das Magazin, July 1973 (http://www.dasmagazin.de/category/heftarchiv/hefte$1973 /)$.
} 
Germany's increasingly emancipatory rhetoric about the female body, coupled with the state's proclaimed ideal of racial heterogeneity - while nonetheless reinforcing certain notions of women as pure and unadulterated, as they swam side-by-side in the nude. Of course, articulations of gender and sexuality would prove to be far more complex during the festival itself.

Those who attended the 1973 festival referred to the events that took place in East Berlin not only as the "Red Woodstock" but also as the "Summer of Love." The well-known East German writer, Ulrich Plenzdorf, who attended both the 1951 and 1973 festivals in East Berlin, noted that, during the earlier festival, it had been his job to monitor the parks: "We recorded the personal details of the people, because there was naturally quite a blessing of children nine months later. I guess that also happened in 1973." ${ }^{84}$ Rumors of Weltfestkinder (festival children) were, in fact, common after the 1973 festival as well. ${ }^{85}$ The festival consequently acquired a reputation for sexual encounters-encounters that occurred on the margins of its monitored and controlled public spaces.

Though aware of such encounters, East German authorities nonetheless attempted to utilize the festival to uphold the state's long-standing commitment to monogamy and heterosexuality, while simultaneously reinforcing deeper taboos concerning relationships with foreigners. The authorities even selected fifteen young couples from across the GDR to celebrate their weddings at the festival. The couples, wearing white dresses and dark suits, were paraded through the city before the international guests, reinforcing the importance of the traditional institutions of marriage and family life in the GDR. ${ }^{86}$ The authorities' decision to select white couples reflected the unspoken norm of privileging marriages between white citizens over interracial marriages or marriages with foreigners. Yet, in order to maintain a semblance of international solidarity, Junge Welt highlighted that Nguyen Duc Soat, a hero of the Vietnamese People's Air Force, had, "in the Vietnamese tradition, wished all the couples a long life [and] many children, and presented them with small gifts: parts from downed US aircraft." 87

Yet, for international youths and workers living in the GDR at the time, the limits of East German solidarity, especially when it came to interracial marriages between East Germans and foreigners, were omnipresent. As Sarah Pugach has argued, "the anxiety surrounding African men who consorted with white women made it clear ... that even if racial biases were denied on an official level, bigotry nonetheless endured." 88 The same year that the festival took place, an international contract worker from Africa submitted a request to GDR authorities to bring his East German partner and their child back home with him. When the authorities denied his request, he submitted a complaint to the Free German Trade Union Federation (Freier Deutscher Gewerkschaftsbund, or FDGB): "It is unthinkable for me to have to return to my homeland without marrying and bringing back my wife and child with me. I can't avoid the impression that there is considerable variation in decisions about marriages between East German citizens and citizens from developing countries

\footnotetext{
${ }^{84}$ See the BpB interview with Ulrich Plenzdorf, "Der Umgang mit der DDR war nicht fair" (http:// www.bpb.de/mediathek/396/der-umgang-mit-der-ddr-war-nicht-fair).

${ }^{85}$ Schiller, "Communism, Youth and Sport," 57.

${ }^{86}$ Wesenberg, "Unter 'operativer Kontrolle,", 17.

${ }^{87}$ Other guests apparently followed his example, presenting gifts to the couples and wishing them well. See "Erstmal musste Holz gesägt werden," Junge Welt, Aug. 4, 1973.

${ }^{88}$ Pugach, "African Students and the Politics of Race and Gender," 132.
} 


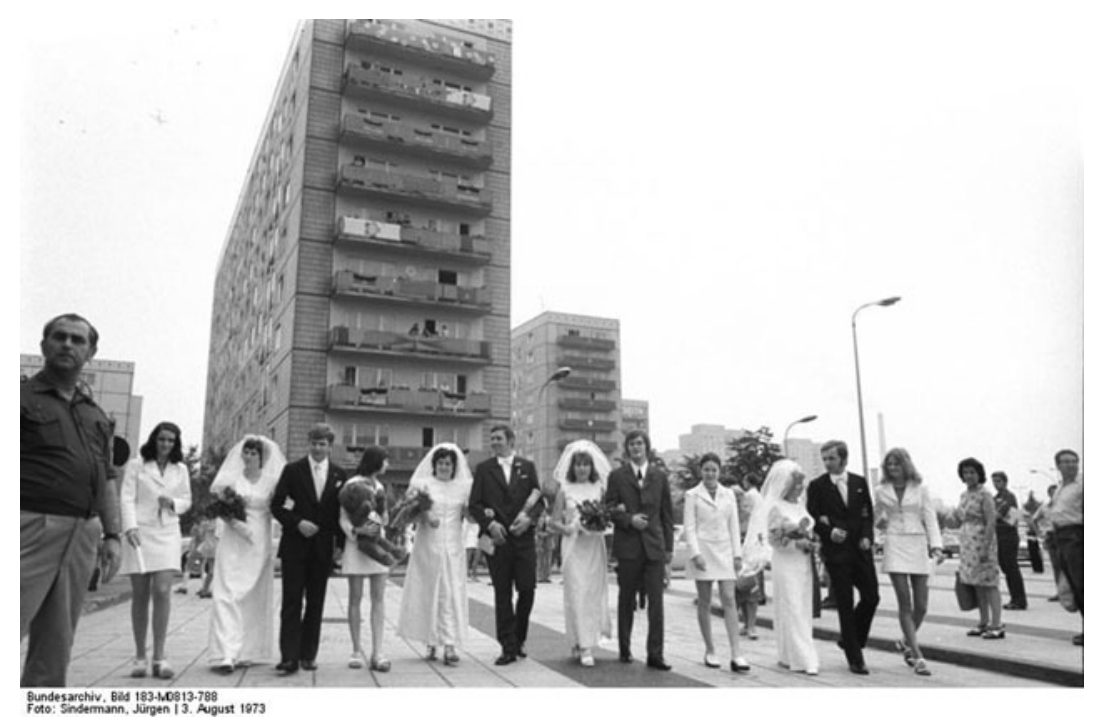

Fig. 5. Newlyweds on the way to the Festival Club in 1973. Source: Bundesarchiv Bild 183-M0813-788 / Photo Credit: Jürgen Sindermann.

which I cannot find any explanation for." 89 Unlike the newlyweds paraded around East Berlin during the festival, such partnerships were far from a cause for celebration for authorities. Despite the state's claims to the contrary, a set of racialized matrimonial norms remained deeply embedded in East German society, leaving their mark on the various rituals that took place not only during the festival but also in everyday life.

Yet, the festival's participants called into question the state's agenda through more open acts of transgression against imposed sexual norms, especially on the subject of gay rights. This was apparent when Peter Tatchell, an Australian participant in the British delegation, collaborated with a group of young people from East and West Berlin to create one of the first gay rights demonstrations in the East German capital. Tatchell had initially used the official meetings during the festival as a forum to advocate for gay rights, resulting in the authorities turning off the microphone and halting simultaneous interpretation of his speech; in the end, he nevertheless managed to deliver it. ${ }^{90}$ The event proved to be just the first of his attempts to defy the East German authorities. Tatchell distributed thousands of leaflets in the streetsnearly resulting in his arrest-before attending the festival's final rally, where he carried a sign across Alexanderplatz that read (in German): "Gay Liberation Front-London, Civil Rights for Homosexuals," and "Gay Liberation: Homosexuals support socialism." 91 The sign introduced a rights discourse that did not condemn East German socialism per se (the GDR had decriminalized homosexuality in 1968, even before West Germany), so much as call into question the East German state's continued heterosexual norms.

\footnotetext{
${ }^{89}$ Quoted in McLellan, Love in the Time of Communism, 110.

${ }^{90}$ See Tatchell's webpage: "Queer Comrades in the East" (http://www.petertatchell.net/lgbt_rights/ history/queer_comrades.htm).

${ }^{91}$ LAB, C Rep 303, 642, Bild Dokumentation 38, [Aug. 1973]. Also see Josie McLellan, "Glad to be Gay Behind the Wall: Gay and Lesbian Activism in 1970s East Germany," Oxford History Workshop Journal 74, no. 1 (2012): 110.
} 
At the time, East German gay and lesbian activists, many of whom were members of the FDJ, were in the midst of launching their own grassroots gay rights movement, which would become known as the Homosexual Interest Group Berlin (HIB). The group had developed connections with their West German counterparts, such as the Homosexual Action West Berlin, but they nonetheless saw themselves as forging a distinctly East German movement. ${ }^{92}$ While Tatchell recalled a number of delegations expressing hostility toward the gay rights movement in general, East German activists and allies also came out in support of his demonstrations. In fact, they even carried their own banners at the final rally that read: "We homosexuals of the capital welcome the participants of the Tenth World Festival and are for socialism in the GDR." 93

The East German state was less than accommodating when it came to the gay rights demonstrations. FDJ officials and police, as well as members of Tatchell's own delegation, made repeated attempts to stop him and others from participating in the rally, ripping up their posters and even threatening and assaulting them. East German officials had also approached Tatchell in a restaurant near Alexanderplatz just prior to the rally, asking him about his intended activities. While it is unclear exactly what transpired, Tatchell claims that, after an initial show of force, he was let go, likely because officials did not want to attract media attention. At the rally, Tatchell again faced resistance from a number of festival participants after he pulled out the gay rights poster: "Ignoring demands that we disband, more than 30 of us decided to march to Marx-Engels Platz and join the rally. We had gone barely forty yards along the road when we were set upon violently by some of the antigay members of the British delegation who had apparently decide to stay behind and keep an eye on us. Fighting them off, we regrouped and marched onwards through Alexanderplatz with the fragment of placard held high."94 In the end, East German youths - both from the HIB and the FDJ-helped Tatchell escape to the rooftop of an apartment building nearby, where they regrouped to watch the fireworks marking the end of the festival. ${ }^{95}$ According to Tatchell's account, he received letters after the festival from sympathizers - including some from as far away as the Long Kesh (Maze) detention center in North Ireland and the ANC of South Africa—who had heard about the gay rights protest. ${ }^{96}$

The gay rights demonstration on Alexanderplatz should not be read as a unique moment of "authenticity," in contrast to the "inauthentic assemblage" of East German and international youths. Nor did it embody a slippage into the unofficial sphere of individual transgressions in the midst of the East German state's official activities. Rather, it represented one of the many articulations of international solidarity that emerged during the festival, though, in this case, one that delineated the borders of an alternative imagined community. In the aftermath of the festival, the gay rights movements on either side of the Berlin Wall would remain

\footnotetext{
${ }^{92} \mathrm{Ibid}$. For the argument that East German activists sought to be part of an international LGBT community, but on "strictly socialist terms," see Scott Harrison's PhD dissertation, "The State of Belonging: Gay Rights Activism in Cold War East Germany, 1949-1990" (forthcoming, University of Illinois, UrbanaChampaign).

${ }^{93}$ On hostility by French and British delegations, see Tatchell, "Queer Comrades in the East." See also Bert Thinius, "Aufbruch aus dem grauen Versteck. Ankunft im bunten Ghetto?," in Schwuler Osten: Homosexuelle Männer in DDR, ed. Kurt Starke (Berlin: Ch. Links Verlag, 1994), 20.

${ }^{94}$ Tatchell, "Queer Comrades in the East."

${ }^{95}$ See Tatchell's interview in the film Out in Ost Berlin: Lesben und Schwule in der DDR, directed by Jochen Hick und Andreas Strohfeldt (Hamburg: Déjà-vu Film UG, 2013).

${ }^{96}$ Tatchell, "Queer Comrades in the East."
} 
interconnected, continuing to forge ties in their struggle to transform the heterosexual norms of both German states, though in different ways. ${ }^{97}$ The demonstration's significance should thus be contextualized not as a fleeting moment of youth defiance indicative of the festival's "upside-down" character, but rather as part of an ongoing fragmented conversation on gay rights that had significance at both the local and global levels.

\section{Conclusion}

The modern festival, like Bakhtin's carnival, offered a space of competing imaginaries that exemplified, rather than subverted, the realities of everyday socialist society. This was partially the case because the festival rituals reflected, while never quite fully conforming to, statesocialist ideals. More important, however, the East German state's embrace of socialist internationalism gave expression to competing subjectivities through the heterogeneity of those who participated in the various solidarity activities. The state's commitment to international socialist solidarity thereby came to exemplify the Bakhtinian "grotesque body" that it could never quite purge from its midst. In this respect, the Red Woodstock festival reinforced a lexicon of resistance within East German public spaces that was internationalist, anti-imperialist, and even revolutionary in its articulation, representing one of the many inherent paradoxes of the East German socialist project.

More generally, the musical performances, late-night discussions, and anti-imperialist expressions of solidarity that the state interwove into the rituals established during the 1973 festival, and even earlier, did not disappear from East German society after the festival's end. Instead, they were ever present in the state's attempt to fuse the state solidarity agenda with various international youth cultural trends during the late socialist period. In turn, young people from the GDR and beyond transformed the East German capital, through the subtle appropriation, transformation, and even outright subversion of the state-generated discourse on international solidarity, in ways that would, time and again, upend East German norms during the late socialist period. ${ }^{98}$

George Washington University

\footnotetext{
${ }^{97}$ Harrison, "The State of Belonging."

${ }^{98}$ Verdery, What Was Socialism, 4.
} 